\title{
The activity of class I, II, III and IV alcohol dehydrogenase isoenzymes and aldehyde dehydrogenase in the sera of bladder cancer patients
}

\author{
Karolina Orywal ${ }^{1 凶}$, Wojciech Jelski ${ }^{1}$, Tadeusz Werel${ }^{2}$ and Maciej Szmitkowski ${ }^{1}$ \\ 1Department of Biochemical Diagnostics and 2Department of Urology, Medical University, Białystok, Poland
}

Objectives. Studies on alcohol dehydrogenase (ADH) and aldehyde dehydrogenase (ALDH) activity in the sera of patients with malignant neoplasms show that cancer cells in many organs may release ADH isoenzymes into the blood. The aim of this study was to investigate the differences in the activity of $A D H$ isoenzymes and ALDH in the sera of patients with bladder cancer (BCa), and with different grades of the disease. Material and Methods. Blood samples were taken from 39 patients with BCa (15 patients with low-grade and 24 with highgrade $\mathrm{BCa}$ ) and from 60 healthy subjects. Class III and IV of ADH and total ADH activity were measured using the photometric method, while class I and II ADH and ALDH activity using the fluorometric method with class-specific fluorogenic substrates. Results. The activity of the class I ADH isoenzyme and total ADH was significantly higher in the sera of $\mathrm{BCa}$ patients as compared to control group. Analysis of ALDH activity did not show statistically significant differences between the tested groups. Significantly higher total activity of ADH in comparison to control was found in both, low-grade and high-grade BCa group. The activity of ADH class I was also significantly higher in high-grade $\mathrm{BCa}$ group when compared to low-grade patients and controls. Conclusion. The increase of total ADH activity in the sera of $\mathrm{BCa}$ patients seems to be caused by isoenzymes released from cancerous cells. The higher activity of ADH I probably resulted from metastatic tumors as significant increase was detected only in the sera of high-grade bladder cancer patients.

Key words: alcohol dehydrogenase isoenzymes, aldehyde dehydrogenase, bladder cancer

Received: 19 March, 2016; revised: 19 May, 2016; accepted: 13 July, 2016; available on-line: 08 October, 2016

¿e-mail: orywalk@umb.edu.pl

Abbreviations: ADH, alcohol dehydrogenase; ALDH, aldehyde dehydrogenase; $\mathrm{BCa}$, bladder cancer; IARC, International Agency for Research on Cancer; NDMA, p-nitrosodimethylaniline; DNA, deoxyribonucleic acid; NAD, nicotinamide adenine dinucleotide; NADH, reduced form of nicotinamide adenine dinucleotide

\section{INTRODUCTION}

Alcohol consumption is the risk factor for over $5 \%$ of male and $1.7 \%$ of female cancer cases worldwide (Boffetta et al., 2006). Despite the large number of published studies, questions about the definite role of ethanol drinking on bladder carcinogenesis remains without unequivocal answers. Components of alcoholic beverages and their metabolites, mostly acetaldehyde, are excreted through the urinary tract and have been detected in urine, which can influence cancer initiation (Tsukamoto et al., 1993).

Acetaldehyde is the product of ethanol oxidation catalyzed by alcohol dehydrogenase $(\mathrm{ADH})$, and it is subsequently transformed into acetate in reaction with aldehyde dehydrogenase (ALDH). According to International Agency for Research on Cancer (IARC) ethanol and acetaldehyde belongs to group 1 of human carcinogens. Acetaldehyde is highly toxic and mutagenic substance, causing sister chromatid exchanges in human cells and interfering with DNA synthesis and repair at many sites in the genome, which results in tumor development $(\mathrm{Li}$ et al., 2016; Amanuma et al., 2015). Moreover, acetaldehyde, by binding to DNA and cellular proteins, forms adducts, which can activate proto-oncogenes, inactivate tumor suppressor genes in replicating cells and inhibit numerous important enzymes of DNA synthesis pathways (Balbo et al., 2016).

In our recent study, we found significant increase of total ADH activity (more than 2.6 times) in bladder cancer cells, compared to healthy bladder tissue. The total activity of ALDH was lower in cancerous cells than in control group. Moreover, a significant increase of isoenzyme class III ADH was stated in cancer group as whole and in the high-grade bladder cancer (unpublished results). These findings suggest the participation of $\mathrm{ADH}$ in bladder cancer development by increased ability of cancer cells to metabolize ethanol into acetaldehyde, and also by causing glutathione depletion, generation of reactive oxygen species in consequence and finally induction of oxidative stress.

Studies on ADH and ALDH activity in the patients with malignant neoplasms showed that the cancer cells in many organs may release $\mathrm{ADH}$ isoenzymes to the blood, which is the reason of elevated activity of the specific isoenzymes in the sera of cancer patients (Orywal and Szmitkowski, 2016). The aim of this study was to investigate the differences in the activity of alcohol dehydrogenase isoenzymes and aldehyde dehydrogenase in the sera of patients with bladder cancer, and with different grades of bladder neoplasm. The results may supplement the knowledge about the disturbances of $\mathrm{ADH}$ and ALDH activity during the course of bladder cancer.

\section{MATERIAL AND METHODS}

\section{Material}

Blood samples were taken before surgery from 39 patients of University's Clinical Hospital in Białystok, 
who was diagnosed with bladder cancer (31 males and 8 females; mean age 66 years, range 52-92 years). All patients were diagnosed with urothelial cell carcinoma. The patients were divided into two groups: 15 patients were classified as low-grade and 24 as high-grade bladder cancer. 19/39 patients were current smokers, 9 were ex-smokers and 11 were lifelong non-smokers. None of the patients had received chemotherapy, radiotherapy or immunotherapy before tissue collection. The control group was composed of blood samples taken from 60 healthy subjects (40 males and 20 females; mean age 58 years, range 51-68 years). 18/60 healthy volunteers were current smokers, 9 were ex-smokers and 33 were lifelong non-smokers. All of the patients from studied and control group had a history of only occasional alcohol consumption.

The research protocol was approved by the Medical University of Białystok's Human Care Committee located in Bialystok, Poland (Approval No R-I-002/267/2015). All patients gave their informed consent for the examination.

\section{Methods}

Determination of total $\mathrm{ADH}$ activity. Total ADH activity was estimated using the photometric method with p-nitrosodimethylaniline (NDMA) as a substrate (Skursky et al.,, 1979). The reaction mixture (2 mL) contained serum $(0.1 \mathrm{~mL}), 1.8 \mathrm{~mL}$ of $26 \mu \mathrm{M}$ substrate solution in $0.1 \mathrm{M}$ sodium phosphate buffer, $\mathrm{pH} 8.5$ and 0.1 $\mathrm{mL}$ of mixture containing $0.25 \mathrm{M}$ n-butanol and $5 \mathrm{mM}$ NAD. The reduction of NDMA was monitored at 440 nm with Shimadzu UV/VIS 1202 spectrophotometer (Shimadzu Europa GmbH, Duisburg, Germany).

Determination of total ALDH activity. Aldehyde dehydrogenase activity was measured using the fluorogenic method based on the oxidation of 6-methoxy2-naphtaldehyde to fluorescent 6-methoxy-2-naphtoate (Orywal et al., 2011). The reaction mixture contained $60 \mu \mathrm{L}$ of serum, $60 \mu \mathrm{L}$ of substrate, $20 \mu \mathrm{L}$ of $11.4 \mathrm{mM}$ NAD and $2.8 \mathrm{~mL}$ of $50 \mathrm{mM}$ sodium phosphate buffer, $\mathrm{pH}$ 8.5. The mixture also contained $50 \mu \mathrm{L}$ of $12 \mathrm{mM}$ solution of 4-methylpyrazole as a specific inhibitor of $\mathrm{ADH}$ activity. The fluorescence was read at the excitation wavelength of 310 and the emission wavelength of 360 nm with Shimadzu RF-5301 spectrofluorophotometer (Shimadzu Europa GmbH, Duisburg, Germany).

Determination of class I and II ADH isoenzymes. Class I and II ADH isoenzyme activity was measured using fluorogenic substrates (4-methoxy-1-naphthaldehyde for class I and 6-methoxy-2-naphthaldehyde for class II) in a reduction reaction according to Wierzchowski et al., (Wierzchowski et al.,, 1989). The assays were performed in a reaction mixture containing serum $(60 \mu \mathrm{L})$, substrate
$(150 \mu \mathrm{L}$ of $300 \mu \mathrm{M})$, NADH $(100 \mu \mathrm{L}$ of $1 \mathrm{mM})$ and $0.1 \mathrm{M}$ sodium phosphate buffer, $\mathrm{pH} 7.6$ (2.69 mL). The measurements were performed with Shimadzu RF-5301 spectrofluorophotometer at the excitation wavelength of $316 \mathrm{~nm}$ for both substrates and the emission of $370 \mathrm{~nm}$ for class I and $360 \mathrm{~nm}$ for class II isoenzyme.

Determination of class III $\mathbf{A D H}$ isoenzyme. The assay mixture for class III alcohol dehydrogenase contained serum $(100 \mu \mathrm{L})$, formaldehyde as the substrate $(100 \mu \mathrm{L}$ of $1 \mathrm{mM})$, glutathione $(100 \mu \mathrm{L}$ of $1 \mathrm{mM})$ and NAD $(240 \mu \mathrm{L}$ of $1.2 \mathrm{mM})$ in $0.1 \mathrm{M} \mathrm{NaOH}$-pyrophosphate buffer, pH 8.0 (Jelski et al., 2014). The final volume was $2 \mathrm{~mL}$. The reduction of NAD was monitored at $340 \mathrm{~nm}$ and $25^{\circ} \mathrm{C}$ with Shimadzu UV/VIS 1202 spectrophotometer.

Determination of class IV $\mathrm{ADH}$ isoenzyme. The assay mixture for ADH class IV activity contained serum $(50 \mu \mathrm{L}), \mathrm{m}$-nitrobenzaldehyde as the substrate $(132$ $\mu \mathrm{L}$ of $80 \mu \mathrm{M})$ and $\mathrm{NADH}(172 \mu \mathrm{L}$ of $86 \mu \mathrm{M})$ in $0.1 \mathrm{M}$ sodium phosphate buffer, pH 7.5 (Orywal et al.,, 2013). The oxidation of NADH was monitored at $340 \mathrm{~nm}$ and $25^{\circ} \mathrm{C}$ with Shimadzu UV/VIS 1202 spectrophotometer.

Statistical analysis. The differences between tested and control groups were evaluated by Mann-Whitney U test. To test the hypothesis, that there is a difference between the two grades of bladder cancer, ANOVA rank Kruskal-Wallis test was performed. Data were presented as mean values \pm standard deviation and median values. Statistically significant differences were defined as comparisons resulting in $p<0.05$.

\section{RESULTS}

The activity of total $\mathrm{ADH}, \mathrm{ALDH}$ and $\mathrm{ADH}$ isoenzymes in the sera of bladder cancer patients was presented in Table 1 . The total activity of alcohol dehydrogenase was significantly higher (about 8.3 times) in the sera of patients with bladder cancer than in healthy subjects $(p<0.001)$. The mean total activity of $\mathrm{ADH}$ was $7.90 \mathrm{IU} / 1$ in the bladder cancer group and $0.95 \mathrm{IU} / 1$ in the control group. The analysis of ALDH activity did not indicate significant differences between the tested group as whole and healthy individuals. The ratio of total ADH activity to ALDH activity in bladder cancer group was much higher (0.94) compared to the control group (0.13).

The comparison of $\mathrm{ADH}$ isoenzymes activities showed that the highest difference was exhibited by class I ADH. The mean activity of this class of isoenzymes in the cancer group increased more than 3 times $(5.86 \mathrm{mIU} / \mathrm{l})$ in comparison to the control level (1.89 $\mathrm{mIU} / \mathrm{l})$. The increase of ADH I activity was statistically significant $(p<0.05)$. The other tested classes of $\mathrm{ADH}$

Table 1. The comparison of ADH isoenzymes and ALDH activity in the sera of bladder cancer patients.

\begin{tabular}{|c|c|c|c|c|c|c|}
\hline Tested Group & $\begin{array}{c}\text { ADH I } \\
\text { Mean } \pm \text { S.D. }\end{array}$ & $\begin{array}{c}\text { ADH II } \\
\text { Mean } \pm \text { S.D. }\end{array}$ & $\begin{array}{c}\text { ADH III } \\
\text { Mean } \pm \text { S.D. }\end{array}$ & $\begin{array}{c}\text { ADH IV } \\
\text { Mean } \pm \text { S.D. }\end{array}$ & $\begin{array}{c}\text { ADH Total } \\
\text { Mean } \pm \text { S.D. }\end{array}$ & $\begin{array}{l}\text { ALDH Total } \\
\text { Mean } \pm \text { S.D. }\end{array}$ \\
\hline Bladder cancer & $5.86 \pm 7.56$ & $16.80 \pm 10.79$ & $15.91 \pm 15.75$ & $14.67 \pm 16.22$ & $7.90 \pm 7.74$ & $8.42 \pm 7.39$ \\
\hline Low-grade $\mathrm{BCa}$ & $3.17 \pm 6.01$ & $15.52 \pm 14.26$ & $8.52 \pm 4.11$ & $13.15 \pm 14.04$ & $7.88 \pm 7.72$ & $7.95 \pm 8.19$ \\
\hline High-grade $\mathrm{BCa}$ & $6.34 \pm 9.77$ & $16.37 \pm 9.61$ & $17.52 \pm 16.11$ & $16.72 \pm 19.36$ & $8.69 \pm 7.83$ & $10.96 \pm 11.62$ \\
\hline \multirow[t]{5}{*}{ Control group } & $1.89 \pm 0.92$ & $14.01 \pm 3.37$ & $8.89 \pm 2.53$ & $12.18 \pm 3.87$ & $0.95 \pm 0.48$ & $7.23 \pm 2.45$ \\
\hline & $\mathrm{p}^{\mathrm{a}}=0.013$ & $\mathrm{p}^{\mathrm{a}}=0.151$ & $\mathrm{p}^{\mathrm{a}}=0.630$ & $\mathrm{p}^{\mathrm{a}}=0.159$ & $\mathrm{p}^{\mathrm{a}}<0.001$ & $\mathrm{p}^{\mathrm{a}}=0.560$ \\
\hline & $\mathrm{p}^{\mathrm{b}}=0.098$ & $\mathrm{p}^{\mathrm{b}}=0.099$ & $\mathrm{p}^{\mathrm{b}}=0.608$ & $\mathrm{p}^{\mathrm{b}}=0.729$ & $\mathrm{p}^{\mathrm{b}}=0.049$ & $\mathrm{p}^{\mathrm{b}}=0.667$ \\
\hline & $p^{c}=0.018$ & $p^{c}=0.210$ & $p^{c}=0.186$ & $p^{c}=0.214$ & $\mathrm{p}^{c}<0.001$ & $p^{c}=0.862$ \\
\hline & $\mathrm{p}^{\mathrm{d}}=0.201$ & $\mathrm{p}^{\mathrm{d}}=0.201$ & $\mathrm{p}^{\mathrm{d}}=0.200$ & $\mathrm{p}^{\mathrm{d}}=0.577$ & $\mathrm{p}^{\mathrm{d}}=0.694$ & $\mathrm{p}^{\mathrm{d}}=0.768$ \\
\hline
\end{tabular}

S.D., standard deviation. BCa, bladder cancer. Statistically significant differences were defined as comparisons resulting in $p<0.05$. Data were expressed as $\mathrm{mIUI/I}\left(\mathrm{ADH}\right.$ total - IU/I). $\mathrm{p}^{\mathrm{a}}$, cancer patients vs controls. $\mathrm{p}^{\mathrm{b}}$, low-grade BCa vs controls. $\mathrm{p}^{\mathrm{c}}$, high-grade BCa vs controls. $\mathrm{p}^{\mathrm{d}}$, low-grade BCa vs high-grade $\mathrm{BCa}$ 


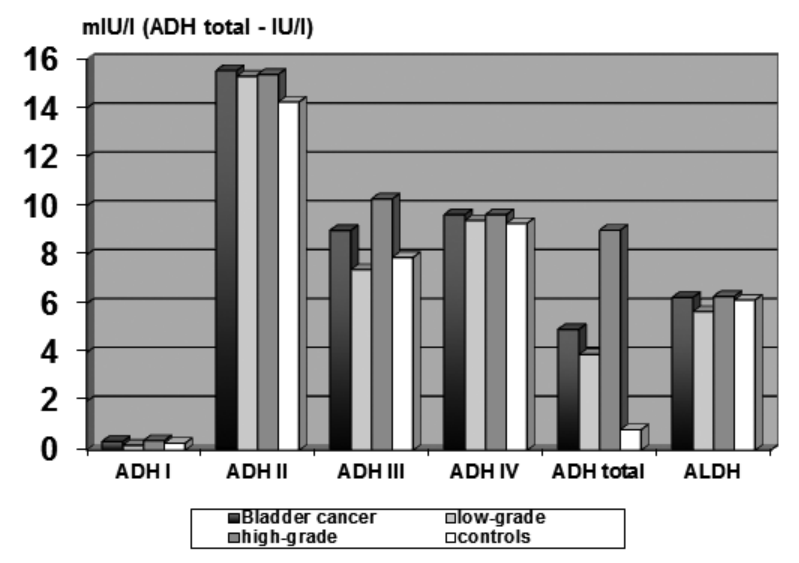

Figure 1. Comparison of ADH isoenzymes and ALDH activity in the sera of bladder cancer patients.

Data are expressed as median values of activity.

isoenzymes had higher activity in the sera of patients with bladder cancer but the differences were not statistically significant.

The comparison of $\mathrm{ADH}$ isoenzymes and ALDH activities in different grades of urinary bladder cancer was presented in the Fig. 1. Significantly higher $(p<0.05)$ total activity of ADH was found in the sera of both, lowgrade $(7.88 \mathrm{IU} / \mathrm{l})$ and high-grade bladder cancer patients (8.69 IU/1), in comparison to healthy volunteers. The activity of ADH class I was significantly higher only in the high-grade bladder cancer group (6.34 mIU/l) compared to low-grade group $(3.17 \mathrm{mIU} / \mathrm{l})$ and controls. The other ADH isoenzymes did not exhibit any characteristic change of activity correlating with the bladder cancer grade. The total activity of ALDH also did not present significant differences between the different grades of the disease.

\section{DISCUSSION}

Urinary bladder cancer represents the $10^{\text {th }}$ most common neoplasia worldwide, with the significant morbidity and mortality. This cancer is the second most prevalent malignant disease in elderly men owing to smoking and industrial exposures and the propensity of the urothelium for metastatic tumours (Jemal et al., 2009). Bladder cancer has a variable metastatic potential and as the result most patients have more than one site of metastasis. Almost any organ can be subjected to bladder cancer metastasis but the most common sites are lymph nodes, bones, lungs, liver and peritoneum (Shinagare et al., 2011). Clinically, $60 \%$ of bladder cancers are lowgrade, whereas $25 \%$ of newly diagnosed bladder cancers are high-grade (Parkin et al., 2000). Low-grade bladder cancer rarely invades the muscular wall of the bladder or spreads to the other organs. High-grade bladder cancer has a strong tendency to invade the muscular wall of the bladder and at least half of high-grade patients develop local and distant metastasis (Wu, 2005).

In our study, we found that the total activity of $\mathrm{ADH}$ was significantly higher in the sera of patients with bladder cancer compared to controls, however, the activity of ALDH was not different between the groups. Significantly higher total $\mathrm{ADH}$ activity was found in the sera of both, low-grade and high-grade bladder cancer patients. In our previous study, significant increase of $\mathrm{ADH}$ total activity was found in bladder cancer cells (low-grade and high-grade) in comparison to normal bladder tissue (un- published results). These findings suggest increased ability to produce acetaldehyde and less capacity to remove it of the bladder cancer cells, compared to normal urinary bladder tissue, which can cause or intensify carcinogenesis in this organ. Our studies are consistent with the published results of ADH and ALDH activities in many malignant diseases. Significantly higher increase of total ADH activity was found both, in the cancer cells and in the sera of patients with neoplasms of esophagus, stomach, liver, pancreas, colorectal, kidney, endometrium and brain (Orywal \& Szmitkowski, 2016). These studies confirmed that changes in enzyme activity in cancer tissue can be reflected in the sera of the patients probably due to releasing the enzyme during the malignancy course.

In the sera of bladder cancer patients we found significantly elevated activity of class $\mathrm{I} \mathrm{ADH}$ isoenzyme. In most malignant diseases, patients have the same class of $\mathrm{ADH}$ isoenzymes concentration elevated in the serum as was in the cancer cells. In the oesophagus and stomach cancer, there was elevated activity of ADH IV, in pancreatic cancer - ADH III and in gynaecological cancers - ADH I, both in cancer tissue and in the sera of the patients (Orywal \& Szmitkowski, 2016). During the course of renal cell carcinoma, elevated activity of $\mathrm{ADH} I$ was found in cancer cells and there was a tendency of ADH I activity to increase in the sera of patients in accordance with the advance of the disease. Significantly higher ADH class I activity was found in every stage (from II to IV) of kidney cancer compared to the control group (Orywal et al., 2015). In the bladder cancer cells, we found significantly higher activity of $\mathrm{ADH}$ isoenzyme class III in the cancer group as whole, compared to healthy bladder cells (unpublished results). In sera of patients with bladder cancer, the activity of class III ADH was more than two times higher than in healthy individuals but the difference was not significant. However, increased activity of this class of ADH seemed to be the result of isoenzymes being released from bladder cancer cells.

It is interesting that in the sera of bladder cancer patients we found elevated levels of the other isoenzyme - ADH I, whose level in bladder cancer cells was similar to that in healthy tissue. It can be the result of isoenzyme being released from metastatic tumours e.g. liver cancer. Human liver contains almost all classes of alcohol dehydrogenase with the highest activity presented by class I. Chrostek and coworkers found that serum activity of class I ADH isoenzymes was significantly higher only in patients with metastatic liver tumors, while in primary tumors there was a tendency for this class activity to decrease (Chrostek \& Szmitkowski, 2000). Metastatic cancers are infiltrating tumors and aggressively act on liver tissue leading to the release of the enzymes from normal liver cells. This hypothesis confirms the fact that the significant increase of the ADH I activity was found only in high-grade bladder cancer. These cancer types very often and easily develop distant metastasis. Furthermore, recent findings showed that polymorphism of alcohol dehydrogenase may be related to bladder cancer. Moderate drinkers with ADH I genotype (gamma1gamma1) appeared to have a threefold higher risk of bladder cancer compared to moderate drinkers with gamma1gamma2 and gamma2gamma2 genotype (Van Dijk et al., 2001). Studies of Jelski and coworkers on breast cancer in women showed that despite of significantly lower ADH I activity in breast cancer cells, compared to normal parenchyma, its activity was higher in the sera of the patients (Jelski et al., 2006a, Jelski et al., 2006b). Significantly elevated activity of ADH I was 
stated only in the blood of patients with stage IV breast cancer as the result of releasing isoenzymes from organs damaged by metastatic disease (Jelski et al., 2006b).

In conclusion, we can state that the activity of class $\mathrm{I} \mathrm{ADH}$ isoenzymes and the total activity of $\mathrm{ADH}$ were elevated in the sera of patients with bladder cancer as compared to the control group. The higher activity of ADH I was probably caused by metastatic tumors as significant increase was presentdetected only in the sera of high-grade bladder cancer patients. The increase of total ADH activity in the sera of bladder cancer patients can be a result of enzymatic disturbances in cancerous cells and isoenzymes (especially ADH III) being released from these cells.

\section{REFERENCES}

Amanuma Y, Ohashi S, Itatani Y, Tsurumaki M, Matsuda S, Kikuchi O, Nakai Y, Miyamoto S, Oyama T, Kawamoto T, Whelan KA, Nakagawa H, Chiba T, Matsuda T, Muto M (2015) Protective role of ALDH2 against acetaldehyde-derived DNA damage in oesophageal squamous epithelium. Sci Rep 5: 14142. DOI: 10.1038/ srep14142

Balbo S, Juanes RC, Khariwala S, Baker EJ, Daunais JB, Grant KA (2016) Increased levels of the acetaldehyde-derived DNA adduct N2-ethyldeoxyguanosine in oral mucosa DNA from Rhesus monkeys exposed to alcohol. Mutagenesis pii: gew016

Boffetta P, Hashibe M, La Vecchia C, Zatonski W, Rehm J (2006) The burden of cancer attributable to alcohol drinking. Int J Cancer 119: 884-887. DOI: $10.1002 /$ ijc. 21903

Chrostek L, Szmitkowski M (2000) The activity of class I and II alcohol dehydrogenase isoenzymes in the sera of patients with liver tumours. Clin Chem Lab Med 38: 409-412

Jelski W, Chrostek L, Markiewicz W, Szmitkowski M (2006b) The activity of alcohol dehydrogenase (ADH) isoenzymes and aldehyde dehydrogenase (ALDH) in the sera of patients with breast cancer. J Clin Lab Anal 20: 105-108

Jelski W, Chrostek L, Szmitkowski M, Markiewicz W (2006a) The activity of class I, II, III and IV alcohol dehydrogenase isoenzymes and aldehyde dehydrogenase in breast cancer. Clin Exp Med 6: 89-93
Jelski W, Laniewska-Dunaj M, Orywal K, Kochanowicz J, Rutkowski R, Szmitkowski M (2014) The activity of alcohol dehydrogenase $(\mathrm{ADH})$ isoenzymes and aldehyde dehydrogenase (ALDH) in the sera of patients with brain cancer. Neurochem Res 39: 2313-2318. DOI: $10.1007 /$ s11064-014-1402-3. Epub 2014 Oct 10

Jemal A, Siegel R, Ward E, Hao Y, Xu J, Thun MJ (2009) Cancer statistics. CA Cancer I Clin 59: 225-2249. DOI: 10.3322/caac.20006. Epub 2009 May 27

Li R, Zhao Z, Sun M, Luo J, Xiao Y (2016) ALDH2 gene polymorphism in different types of cancers and its clinical significance. Life Sci 15: 59-66. DOI: 10.1016/j.lfs.2016.01.028. Epub 2016 Jan 21

Orywal K, Jelski W, Werel T, Szmitkowski M (2015) The activity of class I, II, III and IV alcohol dehydrogenase isoenzymes and aldehyde dehydrogenase in renal cell carcinoma. Exp Mol Pathol 98: 403-406. DOI: 10.1016/j.vexmp.2015.03.012. Epub 2015 Mar 14

Orywal K, Jelski W, Zdrodowski M, Szmitkowski M (2011) The activity of class I, II, III and IV alcohol dehydrogenase isoenzymes and aldehyde dehydrogenase in cervical cancer. Clin Biochem 44: 12311234. DOI: 10.1016/j.clinbiochem.2011.07.004. Epub 2011 Jul 18

Orywal K, Jelski W, Zdrodowski M, Szmitkowski M (2013) The activity of class I, II, III and IV alcohol dehydrogenase isoenzymes and aldehyde dehydrogenase in ovarian cancer and ovarian cysts. $A d v$ Med Sci 58: 216-220. DOI: 10.2478/ams-2013-0012

Orywal K, Szmitkowski M (2016) Alcohol dehydrogenase and aldehyde dehydrogenase in malignant neoplasms. Clin Exp Med. DOI: 10.1007/s10238-016-0408-3

Parkin DM, Bray F, Ferlay J, Pisani P (2001) Estimating the world cancer burden: Globocan 2000. Int I Cancer 94: 153-156

Shinagare AB, Ramaiya NH, Jagannathan JP, Fennessy FM, Taplin ME, Van den Abbeele AD (2011) Metastatic pattern of bladder cancer: correlation with the characteristics of the primary tumor. AJR Am J Roentgenol 196: 117-122. DOI: 10.2214/AJR.10.5036

Skursky L, Kovar J, Stachova MA (1979) Sensitive assay for alcohol dehydrogenase activity in blood serum. Anal Biochem 89: 65-71

Tsukamoto S, Kanegae T, Uchigasaki S et al. (1993) Changes in free and bound alcohol metabolites in the urine during ethanol oxidation. Arukoru Kenkyuto Yakubutsu Ison 28: 441-452

Van Dijk B, van Houwelingen KP, Witjes JA, Schalken JA, Kiemeney LA (2001) Alcohol dehydrogenase type 3 (ADH3) and the risk of bladder cancer. Eur Urol 40: 509-514

Wierzchowski J, Dafeldecker W, Holmquist B, Vallee BL (1989) Fluorimetric assay for isozymes of human alcohol dehydrogenase. Anal Biochem 178: 57-62

Wu XR (2005) Urothelial tumorigenesis: a tale of divergent pathways. Nat Rev Cancer 5: 713-725. DOI: 10.1038/nrc1697 